\title{
Legislative Review and the Voice of Refugees
}

\author{
Shawn Beck and Janice Sanford
}

\begin{abstract}
This statement represents the collective voices of refugee claimants and landed refugees at Romero House, Toronto. It expresses concern over provisions in Not Just Numbers relating to the proposed replacement of the quasi-judicial Immigration and Refugee Board with an administrative unit of the Department of Immigration. Independence of the decision-making process would thus possibly be compromised by the interests of governmental bureaucracy.
\end{abstract}

\section{Précis}

Leprésent texte représente la voix collective de demandeurs du statut de néfugié et de réfugiés installés de la maison Romero de Toronto. Il exprime une inquiétude face à certaines des clauses du rapport Au-delà des chiffres portant sur le remplacement proposé de la Commission sur l'Immigration et les Réfugiés, aux fonctions quasi-judiciaires, par une unitéadministrative du Département de l'Immigration. L'indépendance du processus décisionnel serait dès lors nettement compromis par les intérêts de la bureaucratie gouvernementale.

\section{Introduction}

Romero House is a community of refugee claimants, Convention refugees, refugee resettlement officers (who live and work on a daily basis with claimants), and many others who share our concern for the well-being of refugees. As a grassroots advocacy and resettlement community, we are well equipped to do an analysis of the proposed legislative changes to the immigration act in light of the daily realities of claimants. It

Shawn Beck and Janice Sanford are refugee resettlement officers at Romero House, Toronto. They write on behalf of Assan Amaddin, Awad Amaddin, Sami Durgan, Suleyman Goven, Mohammed Hashi, Keerti Ratanweera and Zeinab Warah. would seem appropriate that the Minister, in considering the report, Not Just Numbers, before her, and desiring to weigh justly all the factors involved, would want to hear what refugees themselves have to say about such an important and comprehensive piece of legislation. The report itself strongly urges a wide and extensive consultation process, involving not only government agencies but also community organizations, advocates, lawyers and the general public (including, one would assume, refugees and immigrants). To our great surprise and dismay, however, we have seen that the Minister is ignoring this wise piece of advice from the report and making a mockery of the entire consultative process.

Be that as it may, we feel that it is important that the choices of refugees be heard. These are the people who have been through the process and know first-hand how legislation impacts on real lives. Since we have not been allowed to present our concerns to the Minister in person, this written submission will have to suffice. The concerns voiced here arise out of the shared experiences of various refugees in the Romero community. Please keep in mind that the following criticisms of the report come not from the academic sector, nor from "professional activists," but rather from real people who have had their lives profoundly shaped over the years through their experiences with Immigration Canada.

\section{Concerns}

This submission lists four major concerns:

1. By far the most pressing concern which refugees have about Not Just Numbers is the replacement of the quasi-judicial determination body, Immigration and Refugee Board (IRB), with a bureaucratic administrative procedure (Sec. 7.7 , iii). ${ }^{1}$
Based on past experiences with immigration officials, refugees fear that too much power and control will be in the hands of the very people who have consistently been problematic in the landing procedure. Refugees have had numerous experiences of arbitrary decision making, stalling, withholding of information, broken promises and outright lies from immigration officials. There is really no trust that these officials, under the new title of "protection officers" would behave any more humanely and fairly in this new schema than they do in the present. Refugees' experience of the immigration bureaucracy is that it is permeated by a culture of discrimination, with an operative agenda quite different from the one promoted as the public face of the Department of Immigration, namely an agenda of intentional exclusion. Without independence from the Department, how can "protection officers" and "appeal officers" make fair decisions unadulterated by political influence? There is no control mechanism for accountability to principles of natural justice built into the administrative determination process. Thus the potential for abuse of the power by bureaucrats is frightening. Weall know that the IRB has its share of problems, but replacing it by a non-judicial agency is not the right solution.

2. Another area of concern for refugees is the question of appeals ( $\mathrm{Sec}, 7.10$, iii, 7). Again, immigration bureaucrats are in charge of the entire appeal process. Where, then, is the independence needed for a fair review? We know that at present the limited appeal options that still exist, namely the Post-Determination Refugee Claimant in Canada Class (PDRCC), consist of the "rubber stamp" procedure. How would the 
appeal process be qualitatively improved under the new system? Also, the timeline set out for appeals (15 days to submit and a further 15 days for new evidence) is arbitrary and unrealistic. It often tales a lot longer to get reliable information on changing country conditions (the former Zarre is a case in point, as was Eritrea several years ago). Again, the report seems to be driven by a draconian need for" cost efficiency" rather than adherence to the demands of natural justice.

5. Not Just Numbers sets out stricter and somewhat arbitrary timelines for the entire determination process (Sec 7.10, ii-iii, 1-7). While refugees certainly acknow ledge the need for reasonable time limits (especially when it comes to the painful waiting process involved in decision making), they are extremely distressed by the initial claim application deadlines (Sec. 7.10, iii, 2) Within thirteenbusiness days of arrival in Canada, refugees are expected to have a full claim submitted. This is ludicrous. Common sense should reveal that other factors such as traumatization, disorientation, language barriers, lack of procedural knowledge and the need to find shelter and food make this time deadline almost impossible to meet. It is hard enough to meet the current twenty-eight day deadline for PersonalInformation Form (PIF) submission, let alone a thirteen-day deadline. Also, it is extremely unclear as to the nature of the claim to be submitted. Is this a PIF? And why are claimants not to be given access to legal counsel until after the submission of a completed protection claim (Sec. 7.10, iii, 3)? The report states that "counseling would be provided at the first opportvnity." But are we to believe that claimants would be fairly" counselled" by the very agency to which they are making their claim? Refugee remain quite skeptica1.

4. Finally, refugees express concern about the whole "safe Third Country" concept (Sec. 7.10, i). With the current realities of "fortress immigration policies in Europe and the United States, it is doubtful that the safe Third Country provisions will be the just and effective way to "restore the original purpose of international humanitarian law." The report states that "Canada could become the repository for those asylum seekers frustrated by safe Third Country bars in countries much closer to the source of the migra tion flow. Some argue that this should be the role for Canada." We are in league with those who support this position. Refugees are legitimately concerned about issues of racism and trade policies coming into play if the Minister is given power to determine safe Third Countries.

\section{Conclusion}

In conclusion, we would like to remind the Minister that changes to immigration legislation, especially such sweeping proposals as those made in Not Just Numbers, affect real people, not just statistics, not just abstract principles. In writing this submission we have tried to represent accurately the views of the refugees who studies sections of the report, met together with us and shared their hopes, concerns and fears about the report if enacted. We urge careful consideration of what they have said, as it is their lives that are impacted, more than those of others well established here. Listen to the refugees' voices, because, in the end, they arenotjustnumbers.1ll

\section{Notes}

1. All citations refer to Not Just Numbers. o

\title{
So That Russia be "Saved" Anti-Jewish Violence in Russia: Its Roots and Consequences
}

\section{By Tanya Basok and Alexander Benifand}

\author{
Toronto: York Lanes Press, 1993; ISBN 1-55014-010-8; 61 pages; \$9.95
}

The growing popularity of ultra-nationalism and neo-Nazism in Europe and to some extent in North America is truly alarming, and this publication offers a perceptive analysis of the political trends in Russia and their implications for Russian Jews. It provides an historical analysis of anti-Jewish violence in Russia and poses an important question: can those conditions which resulted in anti-Jewish pogroms at the turn of the century re-emerge today?

Dr. Basok and Dr. Benifand argue in this occasional paper that there is a number of clear indications of the popularity of the anti-Semitic and ultra-nationalist ideas not only among the masses and nationalist organizations but in the government as well.

Many of those who have been impoverished as a result of the "shock therapy" or who have grown extremely disillusioned with Yeltsin's reform policies, have become attracted to the solutions such as: getting rid of ethnic minorities, especially Jews, territorial expansion of the Russian federation to include the former Soviet republics, the extension of the Russian sphere of influence in Europe and Central Asia, protection of Russian lands (e.g., the Kurile Islands) and the curbing of ethnic nationalism within the Russian federation. Basok and Benifand's insightful analysis is an excellent attempt to understand the rise of ultra-nationalism in Russia. Available from: Centre for Refugee Studies Fax: (416) 736-5837• Email: refuge@yorku.ca 